\title{
Gerhard Thür
}

\section{Two 'Curses' from Mantineia (IPArk 8, IG V2, 262), Prayers for Justice, and Oaths}

Since Kurt Latte ${ }^{1}$ no author on Greek religion and magic has dealt with the famous 'Judgement of Mantineia'2. Lines 24-36 of the inscription seem to pronounce officially two curses on 13 men condemned for murder. Their names are carefully listed at the same square limestone in lines 1-13. The text of the 'curses' runs:

"The following shall be the proclamation (euchola) -: (25) If anyone (present) in the sanctuary is a murderer of those who perished at that time, either himself or any of his descendants in the male line, (a murderer) of either the men or the maiden, it shall be reprehensible (inmenpbes) according to the oracle; if not, it shall be propitious (ilaon).

(30) If Themandros is a murderer of either the men or the maiden who perished at that time in the sanctuary, and was not absent from the deed of violence which took place then, he is to be put in reproach (in monphon th (enai)); if he was absent (at the time) of the deed, and is not a murderer, it shall be propitious (ilaon)." 3

The heading euchola does neither indicate nor exclude a curse. Until now the neutral translation 'official proclamation' seems the best ${ }^{4}$. A contemporary curse tablet from Sicily, Gager 17 (around 450 BC), may have a similar heading eucha, otherwise not attested in defixiones. In favor of his friend Eunikos Apelles 'binds' several rival choregoi. It is a private affair completely different to the Mantineia

${ }^{1} K$. Latte, Heiliges Recht (Tübingen 1920) 45-47; e.g. H. S. Versnel, Beyond Cursing: The Appeal to Justice in Judicial Prayers, in: Cb. A. Faraone, D. Obbink (eds.), Magika Hiera, Ancient Greek Magic and Religion (Oxford 1991) 60-106, and J. G. Gager, Curse Tablets and Binding Spells from the Ancient World (Oxford 1992), do not mention the text.

2 IG V2, 262 (around 460 BC); new edition with legal commentary G. Thür, H. Taeuber, Prozessrechtliche Inschriften der griechischen Poleis: Arkadien = IPArk (SBÖAW ph 607, Vienna 1994) no. 8; text and commentary $H$. van Effenterre, $F$. Ruzé, Nomima II. Recueil d'inscriptions politiques et juridiques de l'archaïsme grec (Rome, Paris 1995) no. 2; $R$. Koerner, Inschriftliche Gesetzestexte der frühen griechischen Polis (Cologne, Weimar, Vienna 1993) no. 34, lines 14-23 only. These authors, on the other hand, don't take note of the new literature on curses and magic (v. supra n. 1).

${ }^{3}$ My translation partly follows C. D. Buck, The Greek Dialects (Chicago 1955) no. 17.

4 IPArk p. 86 n. 26; Nomima II p. 28. 
document. Some authors read the invocation tucha instead of the heading eucha in that case every parallel vanishes ${ }^{5}$.

The text itself refers to a murder case (11. 25-28, 31/32): several men and a maiden were struck at the sanctury that, as we learn from l. 1, belongs to (Athena) Alea ${ }^{6}$. The lines quoted above content two clearly divided paragraphs: the first deals with several persons under suspicion, being at the sanctuary yet ${ }^{7}$, the second deals with a single person, Themandros, who also is suspected. He is said to have been there, but at the moment he is not. He pleads for an alibi. (Finally, his name is included in the list of the 13 persons condemned, ll. 1-13.) In either paragraph generally formulated sanctions, 'reproach' (by the goddess) or 'propitiousness', follow the precisely recorded facts. Up to now, the first alternative, the reproach, caused all scholars to interpret the whole section as a curse.

I. I am doubtful about that. It does not bother me that no divine punishment is proclaimed towards the murderers (under suspicion). Contemporary curse tablets don't do so, either ${ }^{8}$. But, a simple curse would have mentioned at least the names of the persons inflicted ${ }^{9}$. The first paragraph tells not a single name ${ }^{10}$. Every serious attempt has to face the further difficulty that the proclamation formulates an alternative: reproach or propitiousness.

Latte ${ }^{11}$ has suggested a sophisticated solution. Alea whose shrine was violated by the slaughter gave an oracle how to deal with the persons under suspicion: a secular court had to find and condemn the culprits. Latte, therefore, unterstands the text quoted above as a conditional curse. The condition was that secular judges (dikasstai, 1.19) give a sentence on every person accused. I can follow Latte only partly ${ }^{12}$. To sum up: the diskasstai mentioned here are the political authority who proclaimed, with consent by the goddess ("edikasamen", a te theos kas oi dikasstai, 11. 18/19), the euchola to instruct the trials against the persons accused for murder. The verdict was given in two different ways: the defendants who remained in the sanctuary under sacral protection of the goddess were tried by her oracle (1. 14), exactly as provided in the $1^{\text {st }}$ paragraph of the euchola (1.29). These are the first 12 condemned mentioned in the list (ll. 1-12). Themandros - condemned too (1.13) - had to submit to ordinary secular trial, he was sentenced by gnosia (1. 15). If we read the $2^{\text {nd }}$ paragraph of the euchola, concerning Themandros, carefully we neither find him mentioned to be in the sanctuary nor is an

\footnotetext{
${ }^{5}$ Cf. Gager, (s. n. 1.) p. 76 n. 123; Ch. A. Faraone, The Agonistic Context of Early Greek Binding Spells, in: Magica Hiera (s. n. 1) 5 holds eucha.

6 M. Jost, Sanctuaires et cultes d'Arcadie (Paris 1985) 129.369 .374 sq.

7 Cf. Buck, (s. n. 3); IPArk p. 87 n. 29 and 32; A. Chaniotis, Kernos 9 (1996) 76.

${ }^{8}$ Gager, (s. n. 1) p. 5; Faraone, (s. n. 5) 5.

${ }^{9}$ Cf. Gager, (s. n. 1) no. 50, Sicily 475-450 B.C.; the verb parkatagraphein instead of katagraphein seems to indicate an additional private curse added to an official act.

${ }_{10}$ Koerner, (s. n. 2) p. 97 sq. cannot imagine that the oracle did not mention names. Only future offenders are uncertain persons, as the dirae Teiae show ( $\mathrm{SIG}^{3}$ no. $27-38$, Koerner no. 78 ), cf. Faraone, (s. n. 5$) 37$ sq. n. 40.

11 S. n. 1.

12 Cf. my arguments in IPArk p. 91 and Chaniotis, (s. n. 7) 76-78.
} 
oracle mentioned here. So he must have been treated differently from the other twelve.

Recently, van Effenterre ${ }^{13}$ attempts to unterstand the text in a completely different way. The 13 persons (1l. 1-13) are not listed as condemned, they were rather granted amnesty after a time of exile. So the whole document was not a judgement but an act of reconciliation. Since the polis had only secular authority, it could waive only the profane punishments, the confiscation of the houses formerly owned by the condemned persons (1. 17). The sacral inflictments, the banishment from the sanctuary, still were in force. To be quite sure not to offend the goddess the polis proclaimed a conditional curse, our text. Only the goddess really knew whether the persons formerly condemned were guilty or not. The goddess herself may take care. This theory cannot stand. Beside other objections, I cannot imagine how an archaic polis would have granted reconciliation to exiles without admitting them to the official cult ${ }^{14}$.

Nevertheless, both Latte and van Effenterre have strong points. Apart from understanding our text as 'conditional curses' Latte thought that the goddess instructed the trials against the accused persons by an oracle: she gave "Anweisung für den Prozess, vergleichbar auf profanem Gebiet der Instruktion des Praetors an den Judex" 15 . Van Effenterre compares the same text with the usual alternative formulas of questions to an oracle: "La forme est celle des alternatives ordinairement utilisées pour les questions ou réponses d'oracles. " 16 Based on my research on the verb dikazein in archaic sources ${ }^{17}$ I would combine both ideas: the political leaders of Mantineia (the dikasstai, 1. 19) - with consent of the goddess (1.19) pronounced (edikasamen, 1.18) the euchola. This was the first step, the instruction setting the terms for final decision. With Latte we may call this first enactment oracle: an oracle formulating the alternative 'murderer or not murderer' to be decided finally, as far as the 12 first mentioned culprits are concerned, by a further oracle (l. 14 and 29). Based on a similar alternative also enacted by the goddess and the diskasstai (1l. 18/19) Themandros, the $13^{\text {th }}$ on the list (ll. 13 and 30), was condemned by sentence of judges, by gnosia (1. 15).

To sum up, we cannot call our enchola-text simply a curse. The,reproach' by the goddess is provided as sanction against murderers, twelve condemned by divine judgements, one by profane sentence. Only these condemnations result in a curse - as the reproach may be seen to be. Curses seem to be a normal way of handling profane justice. In the whole inscription reproach is the strongest sanction: every amendment of the terms on confiscating the property and exiling the culprits is punished by 'reproach' (1.23) ${ }^{18}$. On the other hand, every condemned

13 Nomima II (s. n. 2) no. 2.

14 G. Thür, Dike 1 (1998) 126.

15 Latte, (s. n. 1) 45 sq.

16 Nomima II (s. n. 2) p. 30; for oracle-questions cf. Versnel, (s. n 1) 81.

17 Cf. G. Thür, Oaths and Dispute Settlement in Ancient Greek Law, in: L. Foxball, A. D. E. Lewis (eds.), Greek Law in its Political Setting (Oxford 1996) 59 with further references.

18 Reproach is a very simple solution. In similar cases of such a 'Bestandsklausel' we find the 
person giving up his property in accordance with the verdict and going to exile will automatically recover 'propitiousness' (1. 22). So, curse and blessing work together in upholding social and political peace in a community that probably did not yet achieve its full constitutional shape ${ }^{19}$.

II. As we have seen, the curses from Mantineia have nothing to do with the private curse tablets discussed in this volume. From a legal point, private curses are a kind of self-help $\mathrm{p}^{20}$ administered in the underground. Nobody boasts in public of such practices or would even confess them privately ${ }^{21}$. Also, when used in legal and political disputes they stay within their unofficial, secret setting. Divine reproach and blessing survived, nevertheless, in the legal system of the classical polis: till now modern scholars did not pay enough attention to the different oaths to be sworn in every lawsuit ${ }^{22}$. Anyway, in the classical period no magistrate was entrusted to handle divine power as freely as the Mantineian authorities apparently did. Surprisingly, in communities not as well organised as Athens we find elements of sacral methods in deciding litigation performed by priests of mighty gods. There are striking parallels to the euchola handed down by chance in the archaic inscription from Mantineia which have never been discussed. These kinds of divine judgement survived in a practice called 'prayers for justice'.

A person who suffered an injustice and was not able or not willing to go to the state authorities had one more remedy, the gods ${ }^{23}$. Many documents from the hellenistic and Roman world show that it worked. The legal historian, of course, is mainly interested in how it worked. At the moment, I am concerned only with the continuity from archaic to hellenistic times. In spite of many similarities to simple private curses there are some distinctive features: in a prayer for justice normally the name of the supplicant is mentioned, in a curse it is not. He or - very often she addresses the god in a humble, flattering language, mentions the wrong he or she suffered (frequently theft or degradation), and in terms of cursing asks for divine punishment unless the culprit would act justly. The act is not a secret magic self-help-binding to prevent a personal enemy from doing future harm - as defixiones in curse tablets are - but, generally, a public step to recover lost property or honor ${ }^{24}$. At least, the culprit is expected to get notice of the prayer and the divine sanctions threatening him ${ }^{25}$. After suffering some personal misfortune, as illness,

sanction of atimia (Dem. 23.62, Drakon's law), a fine of 30 talents and death penalty IPArk 16.4/5 (IG V2.344), a fine of the double of the damage, IPArk 30.14/15 (IG V2.433), a fine of 10.000 drachmae SIG ${ }^{3}$ 976.88-90 (Samos); cf. IPArk p. 88 n. 23 sq.

19 The 'judgement'-inscription dates before the sunoikismos of Mantineia, IPArk p. 77; different opinions Thür, Dike 1 (1998) 128 n. 23.

20 Faraone, (s. n. 5 ) 4.

21 Versnel, (s. n. 1) 62.

22 Too schematicly J. Plescia, The Oath and Perjury in Ancient Greece (Talahassee 1970) 47 sqq.

23 Versnel, (s. n. 1) 68 sqq.

24 A different type are the 'prayers for revenge' e.g. for a killed relative; here the damage is irreparable, and the divine punishment serves exclusively as satisfaction, cf. Versnel, (s. n. 1) 70. 25 For some kind of publicity cf. Versnel, (s. n. 1) 69, 74 and 81. 
death of a relative, or something like that the culprit comes up to the temple, praises the power of the god, confesses and rights his wrong, and sometimes erects a stele to honor the god. So, the extra-judicial procedure may result in a confession inscription ${ }^{26}$.

Here, only the first step, the prayer for justice, is of interest. The most striking parallels between the euchola from Mantineia and the prayers found e.g. in Cnidus $^{27}$ are the alternative formulations: in Mantineia we have the alternative 'guilty or not'; the consequences are 'reproach or propitiousness' (inmenphes or ilaon enai) by the goddess Alea. In Cnidus several prayers concern stolen or lost property. The supplicants ask Damater to punish the persons who won't return the objects stolen or found: "If he gives back it will be according to divine ordonance

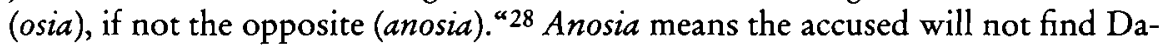
mater well disposed to him (me tuchoi Damatros euilatou) ${ }^{29}$. Both, in Mantineia and in Cnidus, the only sanction against a culprit is that the goddess will be 'not merciful' to him. The terminology changed only slightly: in Mantineia ilaon is used in positive sense, in hellenistic times we find instead of inmenphes a negative me exilatos ${ }^{30}$. The negative divine sanctions immediatly stop when the culprits act justly: in Mantineia the condemned murderers have to go into exile and it will become ilaon again (1.22). In Cnidus the thief has to face unmercyful gods "until" (achris) he restores the stolen garment. The curses are temporary ${ }^{31}$.

There is one essential difference: in Mantineia, the euchola resulted from ordinary jurisdiction. The plaintiffs turned to the political authorities (the dikasstai, 1. 19) who administered divine justice. In Cnidus, a sacred plaintiff' addresses his prayer for justice directly to the gods and asks them to inflict certain evils on his opponent. Divine and profane jurisdiction in Cnidus are strictly separated, a prayer for justice is irrelevant to the profane judiciary.

One other difference seems of minor importance: the euchola mentions both "reproach" and "propitiousness", in a prayer for justice the sacred plaintiff formulates only carefully listed evils.

This reminds one of simple curse tablets. But, lists of threatening evils are common in oath-formulas too. I see parallels between the curse-formulas in the prayers for justice and the double oaths sworn by the parties in every ordinary profane trial ${ }^{32}$. Anachronistically, in classical and hellenistic times those initial oaths survived as a relic of divine justice ${ }^{33}$. Going to court both parties take the risk of perjury. In the same way, a 'sacred plaintiff' is also aware that the curse

${ }^{26}$ Cf. the typology in Versnel, (s. n. 1) 77 and A. Chaniotis, 'Tempeljustiz', in: Symposion 1995, G. Thür, J. Velissaropoulos (eds.), (Cologne, Weimar, Vienna 1997) 353-384.

27 The set of tablets is published now by W. Blümel, Die Inschriften von Knidos I (IK 41.1; Bonn 1992) no. 147-159.

${ }^{28}$ IK 41.1.149 A 8-10, 150 B 3-6, 152 B 2-4, 157.5-7.

29 IK 41.1.147 A 24, 150 A 4.

30 For ileos and euilatos see H. S. Versnel, ZPE 58 (1985) 260-266.

31 IK 41.1.152 A 4-9; a provisional taboo situation, Versnel, (s. n. 1) 73.

32 For the different strength of procedural oaths see Dem. 23.68; cf. Plescia, (s. n. 22).

33 Against this relic Plato, Laws 948b; cf. Thür, (s. n. 17) 64. 
could fall back on himself. Intentionally, a woman formulated a curse upon herself if a slander should turn out true ${ }^{34}$; the curse upon her adversaries has the usual proviso "but it shall be osia for me to be with them ... under the same roof "35. Not only social contact with the 'sacred defendant' being under curse is dangerous but even the prayer for justice itself. Sometimes a 'sacred plaintiff' excuses himself for cursing ${ }^{36}$. More technically, a claimant for returning a deposit - after the well known alternative "to give it back shall be osia, the opposite anosia" (A 8-10) closes the document "for me osia, for those who do not give back anosia" (B 6/ 7) ${ }^{37}$. A prayer for justice bears the same 'sacred risk' as the double oaths in an ordinary trial. In the inscription from Mantineia we only can conclude from gnosia (1.15) that the trials started with double oaths. The euchola does not mention them.

Finally a prayer for justice is a one-sided act, the euchola from Mantineia was enacted by the authorities (dikasstai, 1. 19) after hearing both parties. Apparently, Themandros produced an alibi that found its way into the wording of the euchola (1l. 33,35). No prayer for justice considers a defence plea ${ }^{38}$. Here, the procedure is different from secular trials. The 'sacred defendant' may just wait in full confidence that nothing will happen to him. If his social reputation is stained by his opponent's praying for justice he may take measures by praying himself to reject the slander. No human authority can blur a prayer for justice, only lack of confidence.

34 IK 41.1.147 A 6-28.

35 B 1-7; cf. IK 41.1.148 A 16-B4, 150 A 6-7, 153 B 1-9, 154.22-24, 155.8-11.

36 Versnel, (s. n. 1) 66.

37 IK 41.1.149, cf. 152 A 4-9. The simple proviso "for me osia" 150 B 9, 13/14; 151.11-13; 159.718 .

38 Only in IK 41.1.149 B 8 the text closes with an aposiopesis: "but if they dare to say ..." (the following space is intentionally left free). 